\title{
Analysis of piston microstructure in the most critical zones
}

\author{
S. Manasijevic ${ }^{1 *}$, N. Dolic ${ }^{2}$, M. Djurdjevic ${ }^{3}$, Z. Zovko Brodarac $^{2}$, R. Radisa ${ }^{1}$ \\ ${ }^{1}$ LOLA-Institute, Kneza Viseslava 70a, 11030 Belgrade, Serbia \\ ${ }^{2}$ University of Zagreb Faculty of Metallurgy, Sisak, Croatia \\ ${ }^{3}$ Nemak Europe, Linz, Austria
}

Received 26 August 2013, received in revised form 4 December 2014, accepted 5 March 2015

\begin{abstract}
This paper presents the results of testing the microstructure in the most critical zones of pistons made of aluminum piston alloys. The paper analyzes the shape, size and distribution of primary Si crystals and other phases in three most important piston zones (the edge of the combustion chamber, the area of rings groove and piston pin boss). The phase stoichiometry was identified by comparing the results of EDS analysis with the results reported in the studied literature. The results show that the necessary size, shape and distribution may be obtained in specific zones if appropriate solidification conditions are provided that are necessary for the formation of specific phases.
\end{abstract}

K e y w o r d s: piston, piston alloy, microstructure

\section{Introduction}

Piston alloys are a special group of industrial aluminum alloys that have good mechanical properties at elevated temperatures (approximately up to $350^{\circ} \mathrm{C}$ ) [1], and are resistant to sudden temperature changes [1]. During exploitation, these alloys are exposed to the aggressiveness of the environment in which they are used [1]. Typical aluminum piston alloys are very complex with respect to their chemical composition and the obtained structures. Different piston alloys have various contents of major and minor alloying elements. The usual ranges for some of the alloying elements used by the well-known manufacturers of pistons KS Kolbenschmidt GmbH and MAHLE GmbH from Germany and the local Concern PDM Mladenovac, Serbia are: $11-23$ wt.\% Si; $0.5-3$ wt.\% Ni; 0.5 5.5 wt. $\% \mathrm{Cu} ; 0.6-1.3$ wt. $\% \mathrm{Mg}$; up to 1.0 wt.\% Fe and up to 1 wt. $\%$ Mn [1-4].

Piston alloy microstructure can be very different. It is not accidental but rather affected by the strictly defined rules. The microstructure is caused, on the one hand, by the chemical composition of the alloy and solidification method and, on the other hand, by heat treatment. In the piston alloys, there are at least six elements ( $\mathrm{Al}, \mathrm{Si}, \mathrm{Cu}, \mathrm{Ni}, \mathrm{Mg}$ and $\mathrm{Fe}$ ), which have a significant impact on the solidification path of these alloys. Interactions among them create different phases and intermetallics, the shape and distribution of which in the as-cast and heat-treated alloys depend on the corresponding process parameters. Al-Si piston alloys have a different structure depending on the content of silicon and other alloying elements. The results of previous tests show dependence between the combination of alloying elements, casting conditions and heat treatment given to different microstructures [1-5]. The structural composition of the material has a direct impact on the physical and mechanical properties of the casting.

Taking into account that the $\mathrm{Si}$ crystals are a primary phase in eutectic and hyper eutectic piston alloys, the sequence of solidification is: $\mathrm{L} \rightarrow(\mathrm{Si}), \mathrm{L}$ $\rightarrow(\mathrm{Al})+(\mathrm{Si}), \mathrm{L} \rightarrow(\mathrm{Al})+(\mathrm{Si})+\mathrm{Y}$ and $\mathrm{L}+\mathrm{Y} \rightarrow$ $(\mathrm{Al})+(\mathrm{Si})+\mathrm{Y}$, where $\mathrm{Y}$ is: $\left(\varepsilon-\mathrm{Al}_{3} \mathrm{Ni}, \theta-\mathrm{Al}_{2} \mathrm{Cu}, \mathrm{M}-\right.$ $\mathrm{Mg}_{2} \mathrm{Si}, \delta-\mathrm{Al}_{3} \mathrm{CuNi}\left(\mathrm{Al}_{3} \mathrm{Ni}_{2}\right), \gamma-\mathrm{Al}_{7} \mathrm{Cu}_{4} \mathrm{Ni}, \mathrm{T}-\mathrm{Al}_{9} \mathrm{FeSi}$, $\beta-\mathrm{Al}_{5} \mathrm{FeSi}, \pi-\mathrm{Al}_{8} \mathrm{FeMg}_{3} \mathrm{Si}_{6}$ and $\mathrm{Q}-\mathrm{Al}_{5} \mathrm{Cu}_{2} \mathrm{Mg}_{8} \mathrm{Si}_{6}$ ) [1$5]$, while primary aluminum phase also appears in the microstructure in hypo eutectic alloys. Based on the previous studies of all authors, it has been shown that only these phases may be present in the casting made of Al-Si piston alloys.

Based on the data from the literature, microhard- 
Ta ble 1. Microhardness values

\begin{tabular}{|c|c|c|c|c|c|c|c|c|c|c|}
\hline Phase & $\mathrm{Si}$ & $\mathrm{AlFeMnSi}$ & $\mathrm{Al}_{3} \mathrm{Ni}$ & $\mathrm{Al}_{3} \mathrm{Ni}_{2}$ & $\mathrm{Al}_{7} \mathrm{Cu}_{4} \mathrm{Ni}$ & $\mathrm{Al}_{9} \mathrm{FeNi}$ & $\mathrm{Al}_{5} \mathrm{Cu}_{2} \mathrm{Mg}_{8} \mathrm{Si}_{6}$ & $\mathrm{Al}_{2} \mathrm{Cu}$ & $\mathrm{Mg}_{2} \mathrm{Si}$ & $\mathrm{Al}$ \\
\hline $\begin{array}{l}\text { Hardness } H(\mathrm{GPa}) \\
\text { References }\end{array}$ & $\begin{array}{c}11.5-12.5 \\
{[4,7,8]}\end{array}$ & $\begin{array}{c}10.82 \\
{[7]}\end{array}$ & $\begin{array}{c}10.08 \\
{[7]}\end{array}$ & $\begin{array}{l}10.45 \\
{[7,9]}\end{array}$ & $\begin{array}{l}9.25 \\
{[7,9]}\end{array}$ & $\begin{array}{l}7.71 \\
{[7]}\end{array}$ & $\begin{array}{c}6.51 \\
{[7]}\end{array}$ & $\begin{array}{c}5.57 \\
{[7,9]}\end{array}$ & $\begin{array}{l}4.5 \\
{[4]}\end{array}$ & $\begin{array}{l}1.45 \\
{[7,9]}\end{array}$ \\
\hline
\end{tabular}

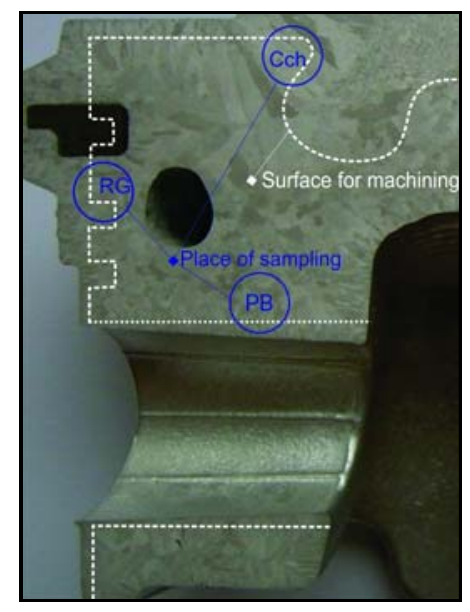

Fig. 1. Piston (casting macro structure).

ness of silicon crystals is $1230 \mathrm{HV}$ [4]. However, in the microstructure of the $\mathrm{Al}-\mathrm{Si}$ piston alloy there are also other phases (Table 1). Based on these microhardness values, it may be concluded that silicon has the role of a phase that reinforces the piston alloy. However, the shape and distribution or dispersion of silicon crystals in the alloy greatly affect the mechanical properties of piston alloys [6]. The conditions of making and modifying these alloys have a great impact on the change in the shape and distribution of crystals.

The shape, distribution and dispersion of microconstituents in the microstructure is not the same in all sections of the piston casting, and piston casting manufacturers strive to create the necessary conditions for forming the needed microstructure in the desired section that provides optimal properties. The zones subjected to greater strain during exploitation (piston pin boss and rings groove) need to have greater resistance to the plastic deformation. This requires a fine grain structure in these zones. A fine grain structure can accumulate a larger quantity of energy [4, $6]$.

In the zones subjected to higher temperatures (i.e., piston head, combustion chamber) but lower mechanical and thermal stresses, a coarse grain is required. Given that higher temperatures stress out thermally actuated processes (diffusion), the material has the potential to compensate deformations that occurred during the temperature decrease. Also, an increase in grain size facilitates slower deformation expansion $[4$,
6]. The structure of the material directly affects the physical and mechanical properties of a casting. For these reasons, it is necessary to define and describe the macro and microstructure, both in terms of quality and quantity, to control the manufacturing process and obtain the required material properties.

Taking into account that the piston casting microstructure, i.e. properties depend on its chemical composition, solidification conditions, and heat treatment, this paper gives an analysis of the microstructure in three critical places of the produced castings.

The main goal of the paper is the shape, size and distribution of primary Si crystals and other phases in three most important piston zones (the edge of the combustion chamber, rings groove and piston pin boss).

\section{Experimental procedure}

The tests were performed on an $\varnothing 89 \mathrm{~mm}$ piston used for an OM604 diesel engine with turbocharger. The mass of the tested piston casting with a pouring system and the feeder is $1275 \mathrm{~g}$, and the mass of the casting is $868 \mathrm{~g}$.

Taking into account that the structure of the material has a direct impact on the physical and mechanical properties of a casting, for this reason, the control of the manufacturing process and the attainment of the desired material properties require that the macro and microstructures present must be defined and described in terms of both quality and quantity (Fig. 1). Measuring the size of the primary crystals was done in three critical zones: combustion chamber, piston pin boss, and rings groove.

The experiment was conducted by producing a sample piston made of aluminum alloys of the chemical composition given in Table 2. The piston casting alloy was melted in an RIO $75080 \mathrm{~kW}$ tub-like electro-resistant inclined furnace with the capacity of $120 \mathrm{~kg} \mathrm{~h}^{-1}$. The $\mathrm{Al}$ alloy was prepared in an RIO 250 $85 \mathrm{~kW}$ electro-resistant muffler-like furnace with black lead muffler.

To improve its mechanical properties, the piston casting was subjected to certain treatments (refining, modification and degasification processes) during its preparation. All three operations were performed at $725 \pm 5^{\circ} \mathrm{C}$. The temperature of liquid casting was measured using a Ni-Cr-Ni digital pyrometer. 
Table 2. Nominal chemical composition of the experimental alloy (wt.\%)

\begin{tabular}{cccccccccccc}
\hline Alloy & $\mathrm{Si}$ & $\mathrm{Cu}$ & $\mathrm{Ni}$ & $\mathrm{Mg}$ & $\mathrm{Fe}$ & $\mathrm{Mn}$ & $\mathrm{Cr}$ & $\mathrm{Ti}$ & $\mathrm{Zr}$ & $\mathrm{V}$ & $\mathrm{Al}$ \\
\hline $\mathrm{A}$ & 12.85 & 3.98 & 1.89 & 1.35 & 0.47 & 0.02 & 0.09 & 0.07 & $\approx 0.03$ & $\approx 0.01$ & residual \\
$\mathrm{B}$ & 12.71 & 1.12 & 1.04 & 1.22 & 0.42 & & & & & & \\
\hline
\end{tabular}

Table 3. Key elements in various intermetallic phases

\begin{tabular}{lccccccc}
\hline Phases & $\mathrm{Al}_{3} \mathrm{Ni}$ & $\mathrm{Al}_{2} \mathrm{Cu}$ & $\mathrm{Mg}_{2} \mathrm{Si}$ & $\mathrm{Al}_{7} \mathrm{Cu}_{4} \mathrm{Ni}$ & $\mathrm{Al}_{9} \mathrm{FeNi}$ & $\mathrm{Al}_{5} \mathrm{FeSi}$ & $\mathrm{Al}_{5} \mathrm{Cu}_{2} \mathrm{Mg}_{8} \mathrm{Si}_{6}$ \\
\hline $\begin{array}{l}\text { Chemical composition } \\
\text { (wt.\%) [3, 4] }\end{array}$ & \multirow{2}{*}{$\mathrm{Ni}$} & $52.5 \mathrm{Cu}$ & $\begin{array}{c}63.2 \mathrm{Mg} \\
36.8 \mathrm{Si}\end{array}$ & $\begin{array}{c}38.5-50.7 \mathrm{Cu} \\
11.8-22.2 \mathrm{Ni}\end{array}$ & $\begin{array}{c}4.5-14.0 \mathrm{Fe} \\
18-28 \mathrm{Ni}\end{array}$ & $\begin{array}{c}25-30 \mathrm{Fe} \\
12-15 \mathrm{Si}\end{array}$ & $\begin{array}{c}20.3 \mathrm{Cu}, 31.1 \mathrm{Mg} \\
32.9 \mathrm{Si}\end{array}$ \\
\hline Key elements [4, 10] & $\mathrm{Ni}$ & $\mathrm{Cu}$ & $\mathrm{Mg}$ & $\mathrm{Ni}, \mathrm{Cu}$ & $\mathrm{Fe}$ & $\mathrm{Fe}, \mathrm{Mn}$ & $\mathrm{Mg}, \mathrm{Cu}$ \\
\hline
\end{tabular}

The investigated pistons were cast in the semi-automatic machines under industrial conditions in Concern PDM, Serbia. The casting was done in a metal mold within the defined internal procedures of the piston manufacturer.

In this case, all piston castings with the chemical composition given in Table 2 were treated with the same heat treatment mode. Homogenization was performed at $510^{\circ} \mathrm{C}$ for $4 \mathrm{~h}$. The homogenization was followed by quenching in water at $20^{\circ} \mathrm{C}$. Then the castings were heat-treated at $180^{\circ} \mathrm{C}$ for $6 \mathrm{~h}$ in an aging process. All castings were marked for the purpose of monitoring the change in the results.

Samples of cast pistons were solution heat treated in a furnace chamber with electric heating, type "KPA 16/32 CER Cacak", with fans for hot air recirculation. The capacity of this furnace is $500 \mathrm{~kg} \mathrm{~h}^{-1}$ and its consumption is $212 \mathrm{kWh}$. The piston castings were automatically quenched by pulling the furnace floor out and lowering the metal basket with pistons directly from the furnace into a water tank. For the aging and stabilization, a CER Cacak EPC 200/300 furnace with the capacity of $3000 \mathrm{~kg} \mathrm{~h}^{-1}$ and the consumption of $180 \mathrm{kWh}$ was employed. The temperature in the furnace was maintained in the prescribed narrow limits $\left( \pm 5^{\circ} \mathrm{C}\right)$, with good atmosphere control.

An optical microscope (Olympus GX51) with magnification up to $1000 \times$ was used for visualizing and collecting data for determining the material microstructure. Sample micrographs were acquired by an Olympus DP70 color digital camera (12.5-megapixel resolution). Metallographic samples were cut out from the piston, polished and electrolytically etched in an HF reagent for $15 \mathrm{~s}$. The samples were observed under a scanning electron microscope (SEM) TESKAN VEGA TS5136LS using magnifications between $200 \times$ and $5000 \times$. Qualitative and quantitative assessments of the chemical compositions of phases were done using an energy dispersive spectrometer (EDS, Bruker).

\section{Results and discussion}

According to available data from literature, Hernández et al. [5] and Manasijevic et al. [1] did a DTA analysis in order to identify phases, while Belov et al. [3] defined a solidification algorithm for aluminum piston alloys. Thus, it can be easily predicted, based on chemical composition, what intermetallic phases are formed. In the microstructure of piston alloy casting in Table 2, the presence of the phases mentioned above was experimentally confirmed. For example, in the microstructure of the piston alloy (Table 1), the presence of the following phases was observed: primary Si crystals, $(\mathrm{Al})+(\mathrm{Si})$ eutectic mixture, binary phases (e.g. $\mathrm{Al}_{2} \mathrm{Cu}$ and $\mathrm{Al}_{3} \mathrm{Ni}_{2}$ ), ternary phases (e.g. $\mathrm{Al}_{7} \mathrm{Cu}_{4} \mathrm{Ni}$ and $\left.\mathrm{Al}_{9} \mathrm{FeNi}\right)$ and quaternary phases $\left(\mathrm{Al}_{5} \mathrm{Cu}_{2} \mathrm{Mg}_{8} \mathrm{Si}_{6}\right)$ and other soluble elements (Fig. 2).

Primary silicon crystals are clearly visible under an optical microscope in both alloys from Table 2. Identification of other complex intermetallic phases present is not possible using optical microscopy, so an SEM was used in this case, which is capable of identifying other phases in combination with EDS. EDS mapping was done to identify better the phases. Each phase has its key elements, as given in Table 3, which can be used to filter the possible crystallographic phases. Also, EDS mapping provides useful information to predict the possible phases where the key elements show higher contrast, as shown in Fig. 2.

The phase composition was also determined using EDS analysis, as shown in Table 3. However, many phases are very hard to identify due to their similar crystal structure and chemical composition $\left(\mathrm{Al}_{7} \mathrm{Cu}_{4} \mathrm{Ni}\right.$ and $\left.\mathrm{Al}_{3} \mathrm{Ni}_{2}\right)$. In addition to the previously listed phases, the following phases were identified: $\mathrm{Al}_{9} \mathrm{FeNi}, \mathrm{Al}_{3} \mathrm{Ni}_{2}$ and $\mathrm{Al}_{7} \mathrm{Cu}_{4} \mathrm{Ni}$ in alloy $\mathrm{A}$, and $\mathrm{Al}_{2} \mathrm{Cu}$, $\mathrm{Al}_{7} \mathrm{Cu}_{2} \mathrm{Fe}$ and $\mathrm{Al}_{3} \mathrm{Ni}$ in alloy $\mathrm{B}$.

Which of the above phases are formed depends on the $\mathrm{Ni} / \mathrm{Cu}$ ratio. By increasing the $\mathrm{Ni}$ content at the expense of $\mathrm{Cu}$, the phase formation goes in the 

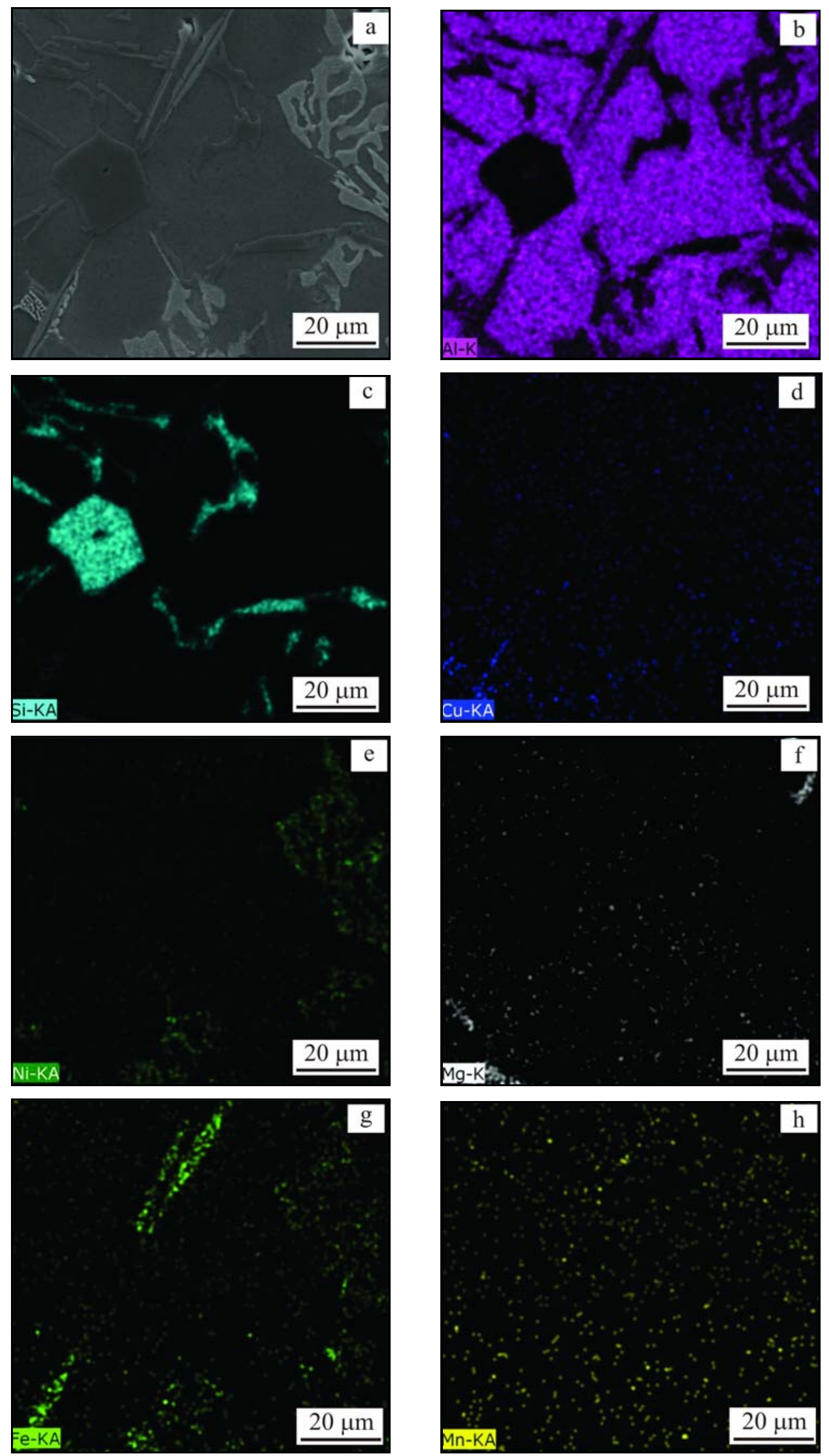

Fig. 2. Microstructure of aluminum piston alloy A: (a) SEM and EDX mapping: (b) Al, (c) $\mathrm{Si}$, (d) $\mathrm{Cu}$, (e) Ni, (f) Mg, (g) $\mathrm{Fe}$, and (h) Mn. 
Ta ble 4. Typical composition of various intermetallic phases observed in the alloy

\begin{tabular}{|c|c|c|c|c|c|c|c|c|c|c|c|c|}
\hline \multirow{2}{*}{ Phase } & \multicolumn{2}{|c|}{$\mathrm{Al}$} & \multicolumn{2}{|c|}{$\mathrm{Si}$} & \multicolumn{2}{|c|}{$\mathrm{Cu}$} & \multicolumn{2}{|c|}{$\mathrm{Ni}$} & \multicolumn{2}{|c|}{$\mathrm{Mg}$} & \multicolumn{2}{|c|}{$\mathrm{Fe}$} \\
\hline & (wt.\%) & (at.\%) & (wt.\%) & (at.\%) & (wt.\%) & (at.\%) & (wt.\%) & (at.\%) & (wt.\%) & (at.\%) & (wt.\%) & (at.\%) \\
\hline \multirow[t]{2}{*}{$\mathrm{Al}_{2} \mathrm{Cu}$} & 63.17 & 79.02 & & & 34.71 & 18.84 & & & & & & \\
\hline & 62.02 & 76.82 & & & 33.77 & 17.76 & & & & & & \\
\hline \multirow[t]{2}{*}{$\mathrm{Mg}_{2} \mathrm{Si}$} & & & 34.51 & 33.24 & & & & & 62.24 & 66.57 & & \\
\hline & & & 33.07 & 33.09 & & & & & 61.78 & 65.66 & & \\
\hline \multirow[t]{2}{*}{$\mathrm{Al}_{9} \mathrm{FeNi}$} & 73.39 & 84.28 & & & & & 13.58 & 7.17 & & & 8.33 & 4.62 \\
\hline & 59.79 & 75.02 & & & & & 25.78 & 14.87 & & & 12.16 & 7.37 \\
\hline \multirow[t]{2}{*}{$\mathrm{Al}_{5} \mathrm{FeSi}$} & 61.24 & 68.57 & 12.38 & 13.93 & & & & & & & 25.38 & 15.50 \\
\hline & 64.01 & 73.31 & 11.57 & 13.28 & & & & & & & 23.61 & 13.07 \\
\hline \multirow[t]{2}{*}{$\mathrm{Al}_{3} \mathrm{Ni}_{2}$} & 40.96 & 54.41 & & & 32.96 & 22.95 & 23.16 & 13.31 & & & & \\
\hline & 32.76 & 40.02 & & & 32.32 & 28.58 & 33.79 & 26.02 & & & & \\
\hline \multirow[t]{2}{*}{$\mathrm{Al}_{3} \mathrm{Ni}$} & 56.35 & 50.28 & & & & & 39.52 & 37.10 & & & & \\
\hline & 59.79 & 55.02 & & & & & 35.78 & 34.87 & & & & \\
\hline \multirow[t]{2}{*}{$\mathrm{Al}_{7} \mathrm{Cu}_{4} \mathrm{Ni}$} & 54.40 & 72.43 & & & 33.06 & 18.69 & 10.74 & 6.58 & & & & \\
\hline & 52.51 & 65.76 & & & 31.67 & 16.84 & 9.23 & 6.44 & & & & \\
\hline \multirow[t]{2}{*}{$\mathrm{Al}_{5} \mathrm{Cu}_{2} \mathrm{Mg}_{8} \mathrm{Si}_{6}$} & & & 31.82 & 30.80 & 20.00 & 20.26 & & & 31.32 & 21.76 & & \\
\hline & & & 30.51 & 31.24 & 21.98 & 19.95 & & & 31.79 & 28.70 & & \\
\hline
\end{tabular}

direction of $\mathrm{Al}_{3} \mathrm{Ni}_{2} \rightarrow \mathrm{Al}_{7} \mathrm{Cu}_{4} \mathrm{Ni} \rightarrow \mathrm{Al}_{2} \mathrm{Cu}$ (or in reverse), which may also be seen in Table 4 based on the changes in composition. The $\mathrm{Al}_{7} \mathrm{Cu}_{4} \mathrm{Ni}$ phase forms in equilibrium with aluminum and some copper can replace nickel in $\mathrm{Al}_{3} \mathrm{Ni}_{2}$.

There is a range of ternary phases, with a structure that varies with composition, and the dissolved copper controls the lattice parameter; nickel has little or no effect.

The typical $\mathrm{Al}_{2} \mathrm{Cu}$ phase given in Table 4 contains higher $\mathrm{Cu}$ and extremely low $\mathrm{Ni}$ contents, and the $\mathrm{Ni}$ ratio can be defined as lower than $5 \%$. In terms of crystal structure and chemical composition, this phase differs greatly from the $\mathrm{Al}_{3} \mathrm{Ni}_{2}$ and $\mathrm{Al}_{7} \mathrm{Cu}_{4} \mathrm{Ni}$ phases, making the identification easier. The next phase that appears is $\mathrm{Al}_{9} \mathrm{FeNi}$. It is characterized by a high chemical content of $\mathrm{Ni}$ and key element $\mathrm{Fe}$, as can be seen in Table 4.

A quaternary phase $\mathrm{Al}_{5} \mathrm{Cu}_{2} \mathrm{Mg}_{8} \mathrm{Si}_{6}$ that appears has a typical composition, given in Table 4 . The typical chemical composition contains a large quantity of $\mathrm{Al}, \mathrm{Si}$ and $\mathrm{Mg}$, with substantial amounts of $\mathrm{Cu}$ (key elements are $\mathrm{Mg}$ and $\mathrm{Cu}$, Table 3). Similarly, the $\mathrm{Mg}_{2} \mathrm{Si}$ phase has a high $\mathrm{Mg}$ content (the key element is $\mathrm{Mg}$, Table 3 ).

During thermomechanical tests of pistons made of alloys A and B (Table 2), alloy A produced better results [4]. This is because there is the formation of phases $\left(\mathrm{Al}_{9} \mathrm{FeNi}, \mathrm{Al}_{3} \mathrm{Ni}_{2}\right.$, and $\left.\mathrm{Al}_{7} \mathrm{Cu}_{4} \mathrm{Ni}\right)$ in alloy $\mathrm{A}$ that show better properties at elevated temperatures.
Figure 3 shows the microstructure of piston castings in their most critical zones (the edge of the combustion chamber, the rings groove and in the most strained section of piston pin boss) for the tested alloys in Table 2. There are the same microconstituents in the compared zones of piston castings, and only their size, shape and distribution differ due to different conditions of cooling, i.e. solidification.

Taking into account that primary Si crystals exhibit the greatest hardness (Table 1), this paper is focused on analyzing them. Figure 3 a shows the microstructure of alloy $\mathrm{A}$ in the edge of the combustion chamber, with the measurement results of the size of primary Si crystals. Figure 3b shows the size of primary crystals of alloy A and the distribution of other phases in the rings groove while Fig. $3 \mathrm{c}$ shows the size of primary crystals in the most strained section of piston pin boss. Figure $3 \mathrm{~d}$ shows the size of primary $\mathrm{Si}$ crystals and the distribution of other phases for alloy B (section of piston pin boss). By comparing this figure with Fig. 3b, it can be observed that, under the same solidification conditions, the two samples taken from the same spot of the piston have different sizes of primary crystals as well as different presence and distribution of other intermetallic phases due to their different chemical compositions.

Figure 4 shows the size of primary crystals in the most critical zones of the piston made of piston alloy in Table 2. Each primary crystal was measured from several directions (M-1, M-2, and M-3). The size 

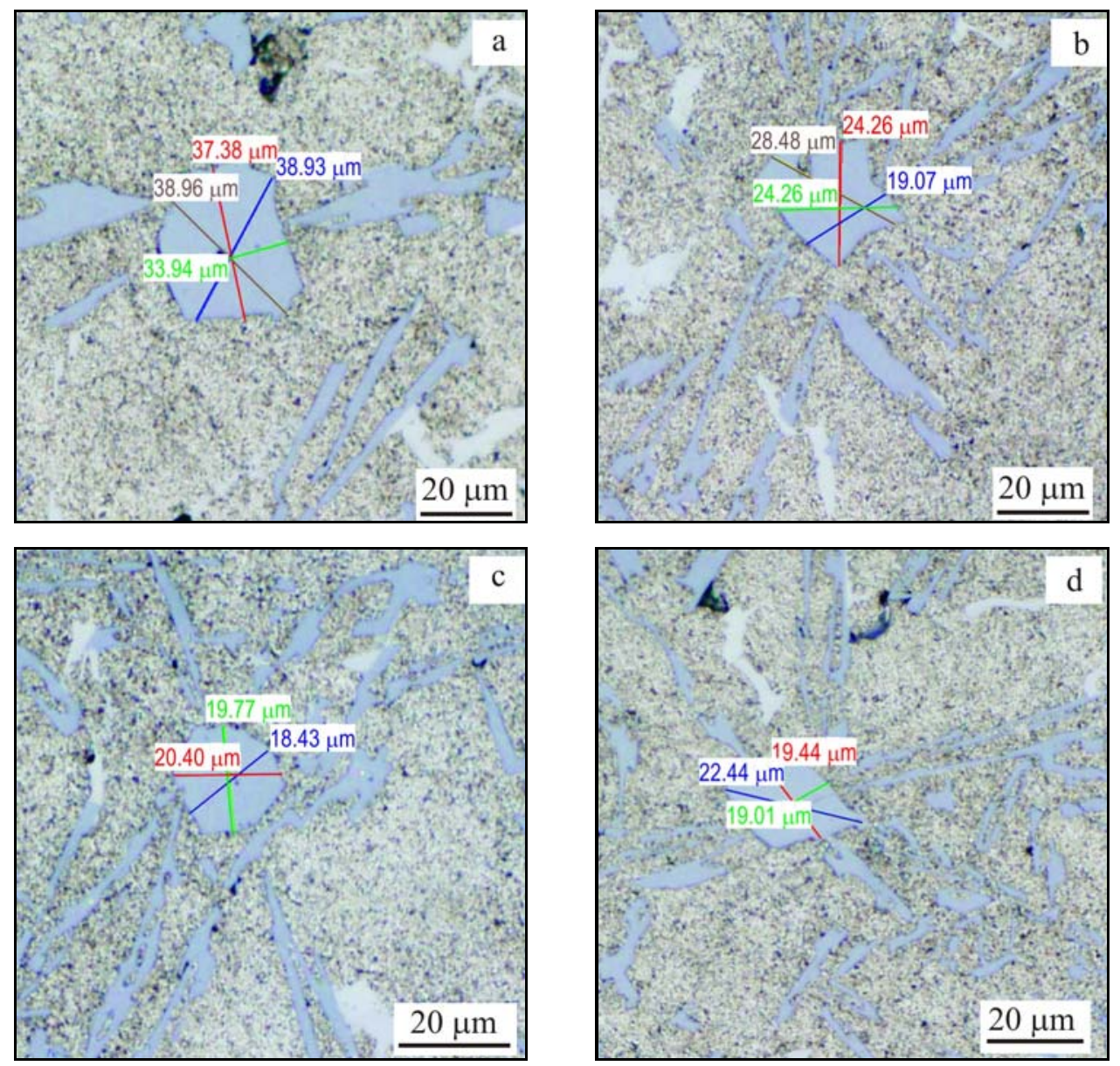

Fig. 3. The shape of created microstructure in critical zones: (a) CCh, alloy A, (b) RG, alloy A, (c) PB, alloy A, and (d) PB, alloy B.

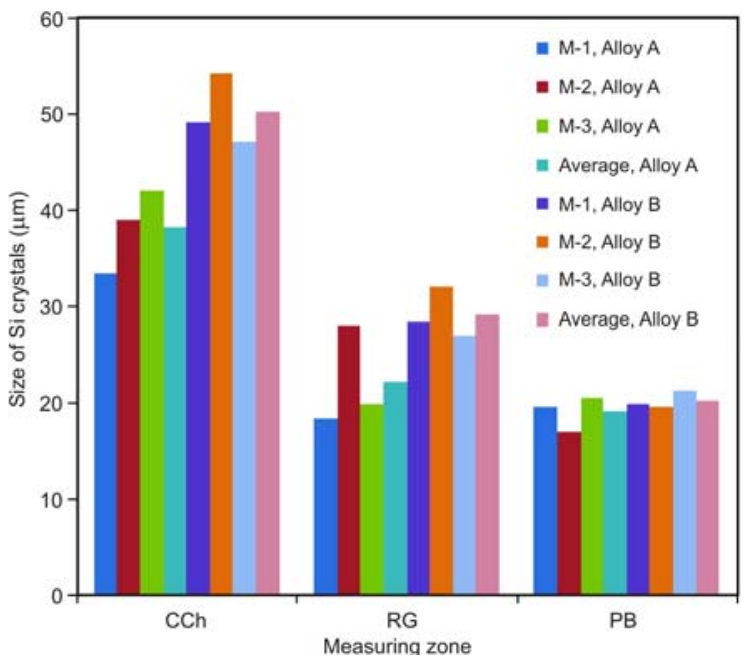

Fig. 4. The size of primary Si crystals in the most critical zones.

of primary $\mathrm{Si}$ crystals in the tested alloy A ranges from $16-21 \mu \mathrm{m}$ (average: $19 \mu \mathrm{m}$ ) in the piston pin boss (PB), $18-28 \mu \mathrm{m}$ (average: $22 \mu \mathrm{m}$ ) in the rings groove
(RG), and $33-42 \mu \mathrm{m}$ (average: $38 \mu \mathrm{m}$ ) in the combustion chamber $(\mathrm{CCh})$ of the piston. The size of primary Si crystals in the tested alloy B ranges from 19-22 $\mu \mathrm{m}$ (average: $20 \mu \mathrm{m}$ ) in the piston pin boss, $26-32 \mu \mathrm{m}$ (average: $29 \mu \mathrm{m}$ ) in the rings groove, and $47-54 \mu \mathrm{m}$ (average: $50 \mu \mathrm{m}$ ) in the combustion chamber of the piston.

\section{Conclusions}

Based on the analysis of the results of experimental tests presented in this paper, it could be concluded:

- the shape, size and distribution of primary crystals and other microconstituents are dependent on solidification conditions;

- an appropriate microstructure may be obtained in each segment of the piston casting by providing the necessary solidification conditions;

- it depends on the $\mathrm{Ni} / \mathrm{Cu}$ ratio, which of the following phases $\left(\mathrm{Al}_{3} \mathrm{Ni}_{2}, \mathrm{Al}_{7} \mathrm{Cu}_{4} \mathrm{Ni}\right.$, and $\left.\mathrm{Al}_{2} \mathrm{Cu}\right)$ are formed. By increasing the $\mathrm{Ni}$ content at the expense of $\mathrm{Cu}$, the phase formation goes in the direction of $\mathrm{Al}_{3} \mathrm{Ni}_{2} \rightarrow \mathrm{Al}_{7} \mathrm{Cu}_{4} \mathrm{Ni} \rightarrow \mathrm{Al}_{2} \mathrm{Cu}$ (or in reverse).

The paper presents the results of identifying the 
phases created in the most critical piston zones. However, this is not sufficient. An optimal combination of needed phases must also be provided to ensure the desired mechanical properties of aluminum piston alloys. The presented results are a part of the research aimed at modeling the solidification process of aluminum piston alloys with pre-defined properties through the identification of created phases, the optimization of the phase share, distribution in the piston casting microstructure, the optimization of relevant technological parameters of casting and their implementation in production through solidification process control and management.

\section{Acknowledgement}

The research presented in this paper was funded by the Ministry of Education and Science of the Republic of Serbia.

\section{References}

[1] Manasijevic, S., Radisa, R., Markovic, S., AcimovicPavlovic, Z., Raic, K.: Intermetallics, 19, 2011, p. 486. doi:10.1016/j.intermet.2010.11.011

[2] Gholizadeh, R. S., Shabestar, G.: Metall Mater. Trans. A, 42, 2011, p. 3447. doi:10.1007/s11661-011-0764-2

[3] Belov, N., Eskin, D., Avxenieva, N.: Acta Mater., 53, 2005, p. 4709. doi:10.1016/j.actamat.2005.07.003

[4] Manasijevic, S.: Aluminum Piston Alloys. Belgrade, Lola Institute Belgrade 2012. ISBN 978-86-912177-1-6

[5] Hernández, R. C., Sokolowski, J. H.: J. Alloys Compd., 419, 2006, p. 180. doi:10.1016/j.jallcom.2005.07.077

[6] Manasijevic, S., Acimovic-Pavlovic, Z., Raic, K., Radisa, R., Kvrgic, V.: Int. J. Cast Metal. Res., 26, 2013, p. 255. doi:10.1179/1743133612Y.0000000007

[7] Chen, C. L., Richter, A., Thomson, R. C.: Intermetallics, 17, 2009, p. 634 . doi:10.1016/j.intermet.2009.02.003

[8] Jang, J. I., Lance, M. J., Wen, S. Q., Tsui, T. Y., Pharr, G. M.: Acta Mater., 53, 2005, p. 1759. doi:10.1016/j.actamat.2004.12.025

[9] Mondolfo, L. F.: Aluminum Alloys: Structure and Properties. London, Butterworth 1976.

[10] Chen, C. L., Thomson, R. C.: J. Alloys Compd., 490, 2010, p. 293. doi:10.1016/j.jallcom.2009.09.181 